\title{
НЕГОСУДАРСТВЕННЫЕ СПОСОБЫ ПРИМЕНЕНИЯ ОПЫТА РАЗВИТЫХ СТРАН ДЛЯ ПОВЫШЕНИЯ ЭФФЕКТИВНОСТИ ОБРАЗОВАТЕЛЬНЫХ УСЛУГ В УЗБЕКИСТАНЕ
}

\author{
Ахтамова Мохигуль Эркиновна \\ Стариий преподаватель. \\ Института экономики и сервиса. \\ Узбекистан. \\ Уразов Садулла Шодиевич \\ ассистент \\ Самаркандского института экономики и сервиса. \\ Узбекистан.
}

Аннотация. В данной статье представлен зарубежный опыт управления образовательными услугами и его реализация в Узбекистане. Организация управления системой образовательных услуг охватывает систему образования Азии и развитых европейских стран и процессы интеграции в образовании.

Abstract. This article outlines the international experience in the management of educational services and the direction of its implementation in Uzbekistan. The systems of organization of educational services in Asia and in developed European countries and integration processes in education are discussed.

Ключевые слова: негосударственные образовательные услуги, интеграция, интеграция образовательных услуг, зарубежный опыт управления образовательными услугами, система образования стран Европы и Азии.

Keywords: nongovernmental educational services, integration, integration of educational services, international experience in the management of educational services, the education system of European and Asian countries.

Вступление. Очевидно, что позитивные изменения, происходящие сегодня в современной системе образования, и интеграция в образовании серьезно влияют на качество негосударственных образовательных услуг.

Образование становится важным условием внедрения новых технологий во все сферы жизнедеятельности человека, повышения конкурентоспособ-ности и уровня жизни. Во многих отношениях социальная ответственность высшего образования заключается в обеспечении того, чтобы каждый стал потребителем на быстро меняющемся рынке труда, в полной мере участвовал в развивающейся инновационной экономике и, таким образом, приобрел навыки и социальные навыки, которые обеспечивают его благополучие и благополучие. общества в целом. ${ }^{1}$.

Обращая внимание на знания молодежи, качество образовательных услуг, Президент сказал: “Мы мобилизуем все силы и возможности нашего государства и общества для того, чтобы наша молодежь была независимой, обладала высоким интеллектуальным и духовным потенциалом.”2- подчеркивает он. Одной из масштабных мер, принимаемых в стране по доведению системы высшего и среднего специального профессионального образования до уровня современных требований, является стремительное развитие образовательных услуг и подготовка новых, конкурентоспособных специалистов в мировой системе высшего образования, в том числе система образования.

Анализ литературы по теме. Хотя система негосударственных образовательных услуг в развитых странах, включая Европу, Германию, Великобританию и Азию, Китай, Сингапур, Южную Корею, Японию иная, организация преподавания и обучения в них отличается разными положительными аспектами. Особенности обучения, исследования образовательных услуг, менеджмент и маркетинг негосударственных образовательных услуг Ю.Н. Геворкян ${ }^{3}$, Е.В. Бурденко ${ }^{4}$, Ш.М.Алиев ${ }^{5}$, Н. В. Варьина ${ }^{6}$ и отражены в научных исследованиях других.

1 Указ Президента Республики Узбекистан от 7 февраля 2017 г. № ПФ-4947 «О стратегии действий по дальнейшему развитию Республики Узбекистан», Собрание законодательства Республики Узбекистан, 2017 г., № 6, ст. 70.

${ }^{2}$ Мирзиёев Ш.М. Вместе мы построим свободное и процветающее демократическое государство Узбекистан. Ташкент: «Узбекистан», 2016. 14-с.

${ }^{3}$ Геворкян Э.Н. Рынок образовательных ресурсов: аспекты модернизации: монография / Е.Н. Геворкян. - М .: Рынок ДС, 2011. - 358 с.

${ }^{4}$ Бурденко Е.В. Рынок образовательных услуг в трансформируемой экономике: Дис ... канд. экон. наука. - М .: РЭА, 2014.

${ }_{5}^{5}$ Алиев Ш.М. Рынок образовательных услуг и вопросы его регулирования: Дис ... канд. экон. наука. - М .: РЭА, 2012.

${ }^{6}$ Варжина Н.В. Формирование систем менеджмента качества образовательных услуг. Диссертация на соискание ученой степени кандидата экономических наук. Екатеринбург 2007 г. -27 c. 
Систематическое исследование образовательных услуг Н. Е. Смольянинов ${ }^{7}$, Ю.С. Васильев ${ }^{8}$, В.А. Долятовский ${ }^{9}$, такие как бывшие союзные ученые К.С. Grenroos $^{10}$, П. Друкер ${ }^{11}$, Ф. Котлер ${ }^{12}$, Альтбах П.Г., Келли Г.П. ${ }^{13}$ такие как зарубежные ученые и отечественные ученые М.К. Пардаев ${ }^{14}$, Э.Г. Набиев ${ }^{15}$, Г. Н. Аксунова ${ }^{16}$, Д.Г. Мухамедова ${ }^{17}$, Исакулова Н, Косимова $3 .{ }^{18}$, Усмонов Н. ${ }^{19}$, Ю. Ерхонова ${ }^{20}$ из отражены в его научных исследованиях.

Методология исследования основана на методах научного абстрагирования, сравнительного анализа и сравнения, методах структурного анализа.

Анализ и результаты. Сегодня в системе государственных образовательных услуг главный упор должен делаться на его результатах, а не на том, как организовано обучение. Образовательные учреждения играют ключевую роль в организации системы негосударственных образовательных услуг. Среди азиатских стран, таких как Китай, Сингапур, Южная Корея и Япония, хорошо развита система образования. Хотя система образования в каждой стране уникальна, конечный результат высок.

В системе высшего образования развитых европейских стран обучение студентов в основном ориентировано на два направления.

Первое направление - адаптация знаний и умений выпускников к требованиям работодателей,

Второе - направить студентов к дальнейшим исследованиям.

Новый подход в системе образования Германии заключается в улучшении аспирантской деятельности студентов, чтобы они могли легко найти свою работу на рынке труда. Суть этой системы в том, что студенты совмещают теорию и практику. Развитые немецкие корпорации заключают соглашения о сотрудничестве с высшими учебными заведениями для решения вопроса организации обучения студентов непосредственно на рабочем месте. Студенты изучают фундаментальные науки, специальности на производственных предприятиях. Аспирант трудоустраивается работодателями в качестве квалифицированного персонала без дополнительного обучения. Предприятия, подписавшие контракт на новую систему образования, будут оплачивать обучение студентов и создавать финансовые стимулы для их проявления инициативы в образовательной и практической работе. Это также будет способствовать повышению интереса студентов к образованию. Студент, желающий учиться по новой системе, заключает договор с работодателем.

Особенность системы образования в Федеративной Республике Германии заключается в том, что основное внимание уделяется учебным планам системы профессионального образования. Стандартная типология компетенций такова, что выпускники образовательных учреждений ориентированы на область своей будущей профессиональной деятельности. Включает предметные, личные и социальные компетенции.

В Германии 250 университетов, из которых 103 - университеты и 176 - университеты прикладных наук. Обучение почти во всех университетах бесплатное как для иностранных, так и для местных студентов. В Германии большинство университетов являются государственными, в то время как существует 69 частных.

${ }^{7}$ Совершенствование управления в сфере дополнительного профессионального образования специалистов. диссертации на соискание ученой степени кандидата экономических наук. Екатеринбург. 2007. - 25 с.

${ }^{8}$ Экономика и организация управления вузом: учебник / под ред. d.e.n. В.В. Глюксова / В.В. Глюксов, М. Федоров, А. Федотов. - СПб .: «Лань», 2001. - 544 с.

${ }^{9}$ В. А. Долятовский, Мазур О.А., Кузнецова И.В., Сакиев Е.Е., Рябченко Т.Н. Стратегическое планирование деятельности вуза на рынке образовательных услуг: Монография. / Стручок красный. В.А. Долятовского, О.А. Мазура.-Ростов-на-Дону-Невинномысск: СКНЦ ВШ-РГЭУ «РИНКС» -НИЭУП, 2005. - С. 14.

${ }^{10}$ Groonros, CA Модель качества обслуживания и маркетинговые последствия / Groonros, C.// European Journal of Marketing.- 1991. - Vol.18, 4.

${ }^{11}$ Дрейкер П. Посткапиталистическое общество // Экономика XXI века - Москва, 1999. - № 11 - С. 3-4

${ }^{12}$ Котлер Ф. Основы маркетинга. - М .: Эконом-пресс, 2005. - С. 265.

${ }_{13}$ Альтбах П.Г., Келли Г.П. Новые подходы к сравнительному образованию. Чикаго и Лондон: Издательство Чикагского университета, 2006. 228 с.

${ }_{14}^{14}$ М.К. Пардаев «Некоторые проблемы экономики сферы услуг» монография Ташкент-2014, 20 стр.

${ }^{15}$ Набиев Г.Е. Сфера услуг в национальном воспроизводстве (теоретические, методологические основы) - Т .: Автреф.к и экон.наук. ТГЭУ, 1993. 18 б.

${ }^{16}$ Маркетинговая деятельность на рынке образовательныах услуг и ее совершенствование: i.f.d.ilm. Автореферат диссертации написан на соискание ученой степени. - Т .: ТДИУ, 2004.

${ }^{17}$ Д.Г. Мухамедова. Совершенствование социально-психологических технологий подготовки менеджеров образования к инновационной деятельности. автореферат докторской диссертации по психологии. Т: 2015 г. -75 млрд

${ }^{18}$ Исакулова Н., Косимова 3. Обучение в зарубежных странах. - Ташкент. 2011. - 106 с.

${ }^{19}$ Усманов Н. Профессиональное образование в Германии. Учеба за границей. Ма'r. 13 февраля 2002 г. 10

${ }^{20}$ Ю. Ерхонова. Критерии французского величия: Обучение за границей. Ма'r. 27 февраля 2002 г. 
В Германии родители учащихся в возрасте до 25 лет могут получить «детское пособие» (Kindergeld) в размере 184 евро. Студенты могут получить беспроцентную студенческую ссуду (BaftsG). Половина этой ссуды, не более 10000 евро, может быть затем возвращена государству (студенты с детьми на первом году обучения освобождаются от этого платежного обязательства).

Помимо получения теоретических знаний в вузах Германии, все большее распространение получает метод обучения, направленный на получение практического опыта на основе работы на предприятии-работодателе. Это двойная система обучения. В Германии система отличается от традиционной системы образования, и, по данным Министерства высшего образования Федерации, около 60\% выпускников немецких школ выразили желание продолжить свое образование в системе Duales Studium.

Перечень специальностей, которые можно получить при дуальном образовании, определяется на законодательном уровне. Сегодня таких специальностей 350. Кросс-тренинг строго контролируется государством.

Срок действия системы Duales Studum составляет 2-3 года. В течение этого периода обучения студент работает 3-4 дня в неделю в компании, с которой у него есть контракт. Студенты получают от 8 до 12 часов профессиональных знаний и в конечном итоге сдают государственные экзамены. Если он не сдаст экзамен, он может его пересдать. Считается целесообразным проводить определенную часть учебного процесса за границей.

Британские университеты занимают особое место в европейской системе образования. Самый большой актив в системе образования Великобритании - это университеты. В зависимости от истории, времени основания их условно можно разделить на три группы. Первый из них - Оксфордский и Кембриджский университет, основанный в средние века в 1096 и 1209 годах и сегодня известный во всем мире. В группу также входят университеты Сент-Эндрюса, Глазго, Абердина и Эдинбурга в Шотландии.

Примером второй группы являются университеты из красного кирпича, основанные в XIX веке в Лондоне, Манчестере, Ливерпуле, Бристоле, Рединге и других городах, где произошли промышленные революции. Их постройки в основном построены из кирпича. Несколько университетов Red Brick занимают лидирующие позиции в рейтинге высшего образования Великобритании.

В Великобритании 90 университетов и 64 других типов высших учебных заведений.

В большинстве университетов Великобритании продолжительность обучения составляет 3 года для степени бакалавра и 1 год для степени магистра (продолжительность зависит от специальности и интенсивности курса). Всего за 3 года преподается 14 предметов, 10 из которых являются базовыми.

В итоге студенты получают дипломы разного уровня в соответствии с их мастерством, то есть студенты получают дипломы разного качества в зависимости от их достижений - первая степень, вторая высшая степень, вторая степень овцы, третья степень, обычный диплом об окончании.

Мы видим, что позитивные изменения, происходящие сегодня в современной системе высшего образования и интеграции в образование, серьезно влияют на качество негосударственных образовательных услуг.

Выводы и предложения. В заключение следует отметить, что в системе высшего образования в основном обучение студентов должно быть направлено по двум направлениям. Если первое направление - адаптировать знания и навыки аспирантов к требованиям работодателей, то второе направление - направить студентов на дальнейшие исследования.

Сегодня, помимо получения знаний в системе негосударственных образовательных услуг, работодатель требует внедрения системы образования Duales Studum, которая направлена на получение практического опыта на основе работы на предприятии. Срок действия системы Duales Studum составляет 2-3 года. В течение этого периода обучения студент работает 3-4 дня в неделю в компании, с которой у него есть контракт. Студенты получают от 8 до 12 часов профессиональных знаний и в конечном итоге сдают государственные экзамены. Если он не сдаст экзамен, он может его пересдать. Этот вид образовательных услуг имеет следующие положительные особенности:

- $\quad$ иметь практические знания и навыки с самых ранних этапов обучения;

- $\quad$ после окончания учебы студент с большей вероятностью найдет работу в интернатуре. 


\section{Рекомендации}

резидент Республики Узбекистан Ислам Каримов подписал Указ 7 февраля 2017 года.О стратегии дальнейшего развития Республики УзбекистанПостановление № ПФ - 4947, г. Собрание законодательства Республики Узбекистан, 2017 г., N 6, статья 70.

2. Мирзиёев Ш.М. Вместе мы построим свободное и процветающее демократическое государство Узбекистан. - Ташкент: «Узбекистан», 2016. 14-с.

3. Альтбах П.Г., Келли Г.П. Новые подходы к сравнительному образованию. Чикаго и Лондон: Издательство Чикагского университета, 2006. 228 с.

4. М.К. Пардаев «Некоторые проблемы экономики сферы услуг» монография Ташкент-2014, 20 стр.

5. Набиев Г.Е. Сфера услуг в национальном воспроизводстве (теоретические, методологические основы) Т .: Автреф.к и экон.наук. ТГЭУ, 1993. 18 б.

6. Д.Г. Мухамедова. Совершенствование социально-психологических технологий подготовки менеджеров образования к инновационной деятельности. автореферат докторской диссертации по психологии. Т: 2015 г. -75 млрд

7. Исакулова Н., Косимова 3. Обучение в зарубежных странах. - Ташкент. 2011. - 106 с.

8. Усманов Н. Профессиональное образование в Германии. Учеба за границей. Ма'r. 13 февраля 2002 г. 10. 